\title{
Effectiveness of essential oil from the Artemisia herba-alba aerial parts against multidrug-resistant bacteria isolated from food and hospitalized patients
}

\author{
ABDELAZIZ ED-DRA ${ }^{1,2}$, FOUZIA RHAZI FILALI ${ }^{1}$, VITTORIO LO PRESTI $^{2}$, BADR ZEKKORI ${ }^{3}$, \\ LUCA NALBONE ${ }^{2, \vartheta}$, EMAN RAMADAN ELSHARKAWY ${ }^{4,5}$, AMAR BENTAYEB ${ }^{3}$, FILIPPO GIARRATANA ${ }^{2}$ \\ ${ }^{1}$ Team of Microbiology and Health, Laboratory of Chemistry-Biology Applied to the Environment, Department of Biology, Faculty of Sciences, Moulay \\ Ismail University. BP. 11201 Zitoune Meknes, Morocco \\ ${ }^{2}$ Department of Veterinary Science, University of Messina. Polo Universitario dell'Annunziata, 98168 Messina, Italy. Tel. +39-90-6766889, \\ `email: Inalbone@unime.it \\ ${ }^{3}$ Team of Physical-Chemistry of Condensed Matter, Department of Chemistry, Faculty of Sciences, Moulay Ismail University. BP. 11201 Zitoune \\ Meknes, Morocco \\ ${ }^{4}$ Department of Ecophysiology, Desert Research Center. 15753, Cairo, Egypt \\ ${ }^{5}$ Department of Chemistry, Faculty of Science, Northern Borders University, 9280, Arar, Saudi Arabia
}

Manuscript received: 17 May 2021. Revision accepted: 28 June 2021

\begin{abstract}
Ed-Dra A, Filali FR, Presti VL, Zekkori B, Nalbone L, Elsharkawy ER, Bentayeb A, Giarrtana F. 2021. Effectiveness of essential oil from the Artemisia herba-alba aerial parts against multidrug-resistant bacteria isolated from food and hospitalized patients. Biodiversitas 22: 2995-3005. The World Health Organization has sounded the warning on the diffusion of multidrug resistance (MDR) bacteria, requiring solutions and alternatives to solve the therapeutic failure that may occur. This study aims to evaluate the antioxidant activity and bactericidal effectiveness against MDR bacteria of Artemisia herba-alba essential oil (A-EO) collected from semi-arid region of Morocco. Chemical composition of the A-EO was determined by Gas Chromatography-Flame Ionisation Detector and Gas Chromatography-Mass Spectrometry, while the antioxidant activity was performed by DPPH scavenging activity and $\beta$ carotene bleaching assay. Antibacterial activity of A-EO, performed by disc diffusion assay and broth dilution method, was tested against: four MDR strains (Escherichia coli, Staphylococcus aureus, Salmonella Typhimurium and Enterococcus faecalis) isolated from food matrices, two (Klebsiella pneumonia and Pseudomonas aeruginosa) from hospitalized patients, and Escherichia coli ATCC 25922 as reference strain. Davanone was the main compound among the 17 identified. An antioxidant activity with IC50 of $1.13 \pm 0.02 \mathrm{mg} / \mathrm{mL}$, EC50 of $2.12 \pm 0.05 \mathrm{mg} / \mathrm{mL}$ and RC50 of $0.87 \pm 0.02 \mathrm{mg} / \mathrm{mL}$ was observed. A weak activity against $P$. aeruginos $a$ was observed, while it was intermediate or high against the other bacteria. This study confirms that A-EO could be a suitable alternative to antibiotics in the infection treatment related to MDR bacteria.
\end{abstract}

Keywords: Antibacterial, antioxidant, Artemisia herba-alba, essential oils, multidrug resistant bacteria

Abbreviations: DPPH: 2,2-diphenyl-1-picrylhydrazyl; TTC: 2, 3, 5-diphenyltetrazolium chloride; AMR: Antimicrobial resistance; AEO: Artemisia herba-alba essential oil; BHI: Brain Heart Infusion; BHT: Butylhydroxytoluene; EOs: Essential oils; FID: Flame Ionisation Detector; GC: Gas Chromatography; MS: Mass spectrometer; MBC: Minimum Bactericidal Concentration; MDR: Multidrug resistance; MHB: Mueller Hinton broth; MIC: Minimum Inhibitory Concentration; RI: Retention index

\section{INTRODUCTION}

During the last years, there has been an increasing interest in phytomedicine. Nowadays, disciplines such as ethnobotany and ethnopharmacology, which aim to study and develop natural drugs to treat patients and validate traditional use of medicinal plants, have aroused growing interest from the scientific community (Anand et al. 2019). In this regard, several herbs and plants were used not only as preventive and therapeutic disease treatments but also as natural additives in foods and beverages (Caceres et al. 1990; Giarratana et al. 2013; Giarratana et al. 2016; Trabelsi et al. 2019; Anand et al. 2020).

Among natural compounds used in phytomedicine, essential oils (EOs) derived from aromatic plants, have been explored and gained prominence (Bakkali et al. 2008).
The EOs can be defined as a complex oily mixture of various organic constituents such as terpenes, sesquiterpenes, phenolic ethers, nitrogen and sulfur compounds responsible for their biological properties (Telci et al. 2006; Langeveld et al 2014). Several authors have demonstrated the antioxidant, anti-inflammatory, and anti-carcinogenic properties of different EOs that have been used against parasites, yeast, mold, and bacteria (Lu et al. 2004; ViudaMartos et al. 2008; Hirota et al. 2010; Giarratana et al. 2014; Giarratana et al. 2017; Ed-Dra et al. 2018a).

The bactericidal activity of EOs could represent a possible solution against the always more diffusion of antimicrobial resistance (AMR), related to the misuse of antibiotics in human and veterinary praxis (Amuka et al. 2013; WHO 2017). The antibiotics used in food-producing animals are often the same as those used in human 
medicine (EFSA and ECDC 2018). As a consequence, bacteria have adapted by developing alternative systems (enzymatic inactivation, modification of drug targets, mechanical protection by biofilm formation) to survive and growth becoming more and more resistant to common treatments (Anand et al. 2019). Not by chance, AMR has been reported in pathogenic, commensal and even environmental bacteria (Maroui et al. 2016; Bouymajane et al. 2018; Ed-Dra et al. 2018b, 2019) and the infections for human-derived by these bacteria are a risk for public health (WHO 2017). For all these reasons the World Health Organization has sounded the warning signal on the diffusion of multidrug resistance (MDR) bacteria, requiring solutions and alternatives to solve the therapeutic failure that may occur (WHO 2017). In this regard, several studies on EOs and plant extracts have been conducted in order to evaluate their potential use as an alternative to antibiotics (Burt 2004).

The biological activity of plants is related to their chemical compounds and is significantly influenced by their growth conditions (Galieni et al. 2015; Hendawy et al. 2018). It is reported that plants are grown in arid regions, in mountains, or soils deficient in certain minerals produce metabolites to withstand stress conditions and possess interesting biological activities (Bohnert et al. 1995; Galieni et al. 2015; El-Shakawy et al. 2017; Pl'uchtová et al. 2018).

Morocco (Northwest of Africa) is known for its diversified climate which favors the development of different kinds of herbs and plants, particularly, in arid and semi-arid regions (Jamila et al. 2014), such as several plants belonging to the genus Artemisia, considered as rich sources of biologically active compounds (Kordali et al. 2005; El-sharkawy et al. 2018; Ez zoubi et al. 2018; Amor et al. 2019; Munda et al. 2019). In particular, several studies have reported interesting biological activities of the Artemisia herba-alba (A) such as antidiabetic, antimicrobial, antitumor, antimalarial, antioxidant, insecticidal and neurological properties (Ez zoubi et al. 2018; Amin et al. 2019; Amor et al. 2019; Mohammed et al. 2021) which, moreover, thrives in Morocco. Since ancient times, A. herba-alba was widely used as a traditional medicine especially in the area of the Mediterranean basin and, nowadays, it is still used as a natural remedy in the household (Gacem et al. 2020). The farm of this plant could represent a significant economic source, especially for the rural population, besides a new and "green" medical and pharmacological solution in the perspective of more sustainable world development (EdDra et al. 2021; Trabelsi et al. 2021).

Therefore, in order to support the efforts for searching of new antimicrobial substances, the aims of this study were: to determine the chemical composition of A-EO collected in a semi-arid region in Morocco, evaluate its bactericidal effectiveness against six different MDR bacteria and its antioxidant activity by using different invitro assays. The novelty of this study is that, to the best of the Authors' knowledge, it describes for the first time the chemical composition, the in-vitro antibacterial and antioxidant activities of EO of A. herba-alba harvested from Talsint, a semi-arid region in the East of Morocco.

\section{MATERIALS AND METHODS}

\section{Plant collection}

The aerial parts (leaves and flowers) of A. herba-alba (about 10 kilograms) were collected during March 2017, from the semi-arid region of Morocco (Talsint region in the East of Morocco) at an altitude of approximately 1350 meters (Lat: 32³0'54.273" Long: 3²7’0.536") (Figure 1). The plants were identified according to the procedure described by Fennane et al. (1999), by the botanist Professor Ibn Tattou Mohammed at the Scientific Institute of Rabat (Morocco). A sample was deposited in a herbarium at the faculty of Sciences Meknes under the voucher number "FSM061A". The collected plant was airdried in the absence of light for 15 days at room temperature $\left(25 \pm 2^{\circ} \mathrm{C}\right)$.

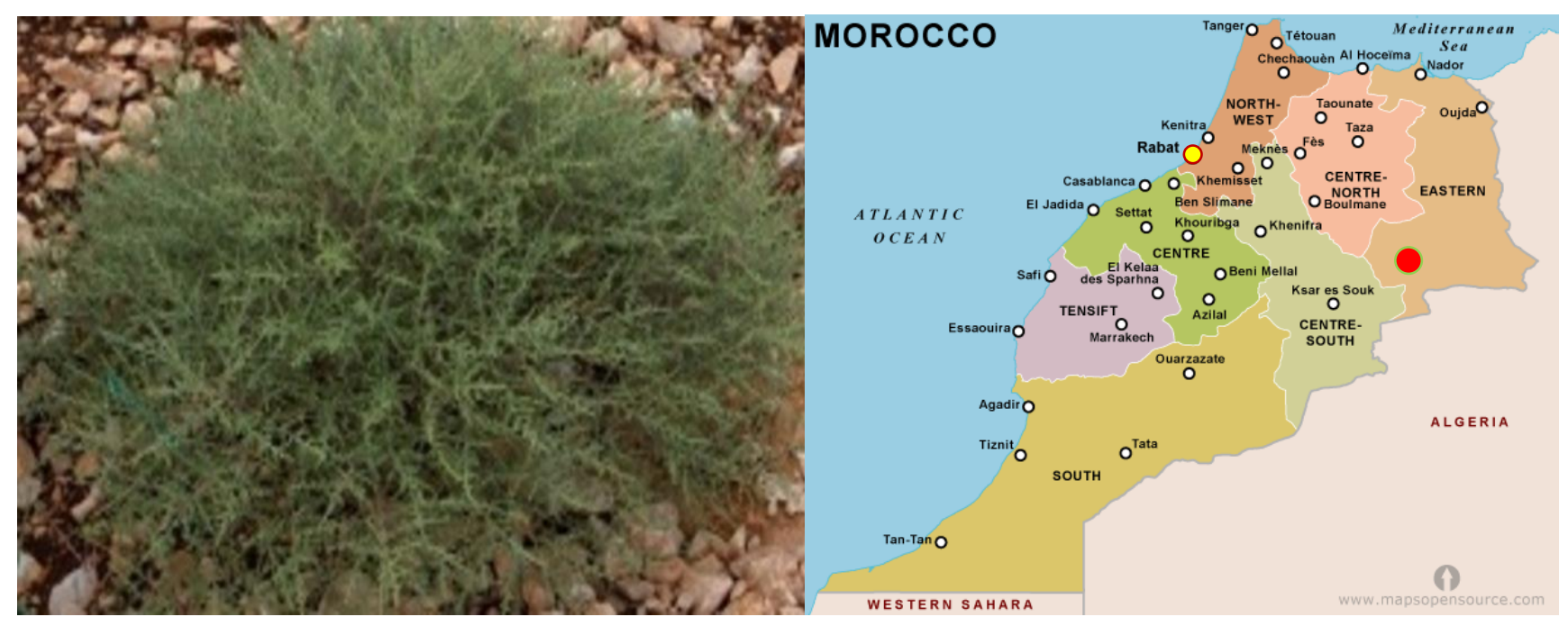

Figure 1. Study plant of Artemisia herba-alba from Talsint (red mark), a semi-arid region in the East of Morocco 


\section{Extraction of essential oil}

Extraction of EO was done by hydro-distillation as follows: 200 grams of dried samples were immersed in $1 \mathrm{~L}$ of distilled water using a flask of $2 \mathrm{~L}$ and then boiled for three hours using a Clevenger-type apparatus (IsoLab Laborgeräte $\mathrm{GmbH}$, Wertheim, Germany). Five different hydro-distillation were performed in the same conditions during two successive days to obtain sufficient EO. The extracted EO of the five hydro-distillation was recovered, grouped, dried by adding anhydrous sodium sulfate (Sigma-Aldrich, Buchs, Switzerland), and stored in a tinted glass bottle at $4^{\circ} \mathrm{C}$ until uses.

\section{Chemical composition: GC analysis}

The analyses were carried out by a Gas Chromatography (GC) (Agilent 6890N) equipped with an HP-5MS capillary column $(50 \mathrm{~m} \times 0.200 \mathrm{~mm}$ i.d., film thickness $0.33 \mu \mathrm{m}$ ) and a Flame Ionization Detector (FID) setting at $250{ }^{\circ} \mathrm{C}$. The $\mathrm{GC}$ oven temperature was programmed to increase from 60 to $250{ }^{\circ} \mathrm{C}$ at a rate of 4 ${ }^{\circ} \mathrm{C} / \mathrm{min}$ and finally held for $15 \mathrm{~min}$. Helium was used as the carrier gas at a flow rate of $1.1 \mathrm{~mL} / \mathrm{min}$ with a split ratio equal 1/100. The samples were also analyzed by GC/MS using an Agilent 6890N Gas Chromatography equipped with an Agilent 5973 Inert Mass Selective Detector under the conditions described above. The transfer line temperature was $250^{\circ} \mathrm{C}$. The quadrupole mass spectrometer was scanned over the $35-465 \mathrm{~m} / \mathrm{z}$ with an ionizing voltage of $70 \mathrm{eV}$ and an ionization current of $150 \mathrm{~mA}$.

Component identification was based on a comparison of mass spectra with mass spectra libraries (NIST MS SEARCH 2.0) and a comparison of the retention index (RI) of the components measured relative to n-alkanes on nonpolar columns with those present in literature data (Salido et al. 2004; Mohsen and Ali 2009; Paolini et al. 2010;
Ouaritini et al. 2016; El-sharkawy et al. 2018; Amor et al. 2019). The percentage of composition of EOs was determined from the FID response without applying correction factors.

\section{Antibacterial activity of A-EO: Selection of MDR strains}

A-EO was tested against six different MDR bacteria, of which 4 Gram-negative: Salmonella enterica subsp. enterica serovar Typhimurium, Klebsiella pneumonia, Pseudomonas aeruginosa and Escherichia coli; and 2 Gram-positive: Staphylococcus aureus and Enterococcus faecalis.

The strains were selected based on the MDR profile (Table 1), previously performed according to the disc diffusion method (CLSI 2014). E. coli, S. aureus, S. Typhimurium and E. faecalis have been isolated from food samples in the Laboratory of Microbiology and Health at the Faculty of Sciences, Meknes (Morocco). K. pneumonia and $P$. aeruginosa were, instead, collected from hospitalized patients in the Regional Hospital of Meknes (Mohammed V Hospital).

In addition, E. coli ATCC® 25922TM strain, belonging to the strains collection of the Laboratory of Microbiology and Health at the Faculty of Sciences, Meknes (Morocco), was used as reference strain of this study. This strain, as reported in the ATCC product sheet, is a recommended reference strain for antibiotic susceptibility testing, and it is used in the susceptibility disc testing of neomycin, colistin, kanamycin, cephalexin, gentamicin, cefamandole, cephalothin, tetracycline, cephaloglycin, cephaloridine, nalidixic acid, and chloramphenicol.

All the strains were stored at $-80^{\circ} \mathrm{C}$ in Brain Heart Infusion (BHI) (Biolife, Milan, Italy) plus $15 \%$ of Glycerol (Biolife, Milan, Italy). Before each test, all bacterial strains were cultured overnight at $37^{\circ} \mathrm{C}$ in Mueller Hinton broth (MHB) (Biokar, Beauvais, France).

Table 1. MDR profile of the six selected bacteria

\begin{tabular}{|c|c|c|c|c|c|c|}
\hline \multirow{2}{*}{ Antibiotics } & \multicolumn{3}{|c|}{ Food matrices } & \multicolumn{3}{|c|}{ Hospitalized patients } \\
\hline & E. coli & S. Typhimurium & S. aureus & E. faecalis & K. pneumonia & P. aeruginosa \\
\hline Chloramphenicol $(30 \mu \mathrm{g})$ & $\mathrm{S}$ & $\mathrm{S}$ & $\mathrm{S}$ & $\mathrm{S}$ & $\mathrm{R}$ & $\mathrm{nt}$ \\
\hline Ciprofloxacin $(5 \mu \mathrm{g})$ & $\mathrm{S}$ & $\mathrm{S}$ & $\mathrm{S}$ & $\mathrm{R}$ & $\mathrm{R}$ & $\mathrm{R}$ \\
\hline Ampicillin $(10 \mu \mathrm{g})$ & $\mathrm{R}$ & $\mathrm{R}$ & $\mathrm{R}$ & $\mathrm{R}$ & $\mathrm{R}$ & nt \\
\hline Amoxicillin-clavulanic acid $(20 / 10 \mu \mathrm{g})$ & $\mathrm{R}$ & $\mathrm{S}$ & nt & nt & $\mathrm{R}$ & $\mathrm{R}$ \\
\hline Penicillin (10 UI) & nt & nt & $\mathrm{R}$ & $\mathrm{R}$ & nt & nt \\
\hline Ceftazidime $(30 \mu \mathrm{g})$ & $\mathrm{S}$ & $\mathrm{S}$ & nt & nt & nt & $\mathrm{R}$ \\
\hline Ceftriaxone $(30 \mu \mathrm{g})$ & $\mathrm{S}$ & $\mathrm{S}$ & nt & nt & $\mathrm{R}$ & $\mathrm{R}$ \\
\hline Cefotaxime $(30 \mu \mathrm{g})$ & $\mathrm{S}$ & $\mathrm{S}$ & nt & $\mathrm{nt}$ & $\mathrm{R}$ & $\mathrm{R}$ \\
\hline Oxacillin $(5 \mu g)$ & $\mathrm{nt}$ & $\mathrm{nt}$ & $\mathrm{S}$ & $\mathrm{nt}$ & nt & nt \\
\hline Ticarcillin $(75 \mu \mathrm{g})$ & $\mathrm{nt}$ & $\mathrm{nt}$ & nt & $\mathrm{nt}$ & nt & $\mathrm{R}$ \\
\hline Imipenem $(10 \mu \mathrm{g})$; & nt & nt & nt & $\mathrm{S}$ & nt & $\mathrm{S}$ \\
\hline Streptomycin $(10 \mu \mathrm{g})$ & $\mathrm{R}$ & $\mathrm{R}$ & nt & $\mathrm{R}$ & $\mathrm{R}$ & nt \\
\hline Tobramycin $(30 \mu \mathrm{g})$ & nt & nt & $\mathrm{nt}$ & nt & $\mathrm{nt}$ & $\mathrm{R}$ \\
\hline Gentamicin $(30 \mu \mathrm{g})$ & $\mathrm{S}$ & $\mathrm{S}$ & $\mathrm{S}$ & $\mathrm{S}$ & $\mathrm{S}$ & nt \\
\hline Amikacin $(30 \mu \mathrm{g})$ & S & $\mathrm{S}$ & $\mathrm{nt}$ & $\mathrm{nt}$ & $\mathrm{S}$ & $\mathrm{S}$ \\
\hline Piperacillin $(100 \mu \mathrm{g})$ & nt & nt & nt & nt & nt & $\mathrm{R}$ \\
\hline Trimethoprim-sulfamethoxazole $(1.25 / 23.75 \mu \mathrm{g})$ & $\mathrm{R}$ & $\mathrm{S}$ & $\mathrm{S}$ & nt & $\mathrm{R}$ & $\mathrm{nt}$ \\
\hline Erythromycin $(15 \mu \mathrm{g})$ & $\mathrm{nt}$ & $\mathrm{nt}$ & $\mathrm{R}$ & $\mathrm{S}$ & nt & nt \\
\hline Vancomycin $(30 \mu \mathrm{g})$ & nt & $\mathrm{nt}$ & $\mathrm{S}$ & $\mathrm{S}$ & nt & nt \\
\hline Tetracycline $(30 \mu \mathrm{g})$ & $\mathrm{R}$ & $\mathrm{S}$ & $\mathrm{R}$ & $\mathrm{R}$ & nt & nt \\
\hline
\end{tabular}

Note: nt: not tested; S: sensitive and R: resistant according to CLSI (2014) 


\section{Antibacterial activity of A-EO: Disc diffusion method}

A bacterial suspension in MHB of a density equivalent to 0.5 MacFarland $\left(10^{8} \mathrm{cfu} / \mathrm{mL}\right)$ was prepared and inoculated by swabbing onto Petri plates containing Mueller Hinton agar (Biokar, Beauvais, France). On the surface of each Petri plate, sterile blank disks $(6 \mathrm{~mm}$ diameter) dropped with $10 \mu \mathrm{L}$ of A-EO were deposited and another one dropped with $10 \mu \mathrm{L}$ of DMSO (Sigma-Aldrich, Buchs, Switzerland) was used as a negative control. Disks of Gentamicin at $10 \mu \mathrm{g}$ (Oxoid, Basingstoke, UK) were used as a positive control for $E$. coli, S. typhimurium, $S$. aureus, K. pneumoniae and E. faecalis, while Imipenem at $10 \mu \mathrm{g}$ (Oxoid, Basingstoke, UK) was used for $\mathrm{P}$. aeruginosa. All Petri plates were incubated at $37^{\circ} \mathrm{C}$ for 24 hours. Then, diameters were measured in millimeters and expressed as means \pm standard deviation of three replicates. The antibacterial activity was classified into three levels: weak (inhibition zone $\leq 12.0 \mathrm{~mm})$, intermediate $(12.1 \mathrm{~mm} \leq$ inhibition zone $\leq 20.0 \mathrm{~mm}$ ) and strong (inhibition zone $\geq$ $20.1 \mathrm{~mm}$ ) (Ed-Dra et al. 2020).

\section{Antibacterial activity of A-EO: Determination of MIC and MBC}

Determination of Minimum Inhibitory Concentration (MIC) and Minimum Bactericidal Concentration (MBC) was carried out by the broth dilution method using 96-well microtitration plate (Chebaibi et al. 2016). Briefly, decreasing concentrations of A-EO (final concentrations vary between 20 and $0.039 \mathrm{mg} / \mathrm{mL}$ ) were prepared in microplates by using Dimethyl sulfoxide (DMSO). Then, $20 \mu \mathrm{L}$ of 0.5 MacFarland bacterial suspensions and $140 \mu \mathrm{L}$ of MHB were added respectively, and the microplates were incubated at $37^{\circ} \mathrm{C}$ for 24 hours. After incubation, the playback was carried out by adding $40 \mu \mathrm{L}$ of 2, 3, 5diphenyltetrazolium chloride (TTC) (Sigma-Aldrich, Buchs, Switzerland) with a concentration of $0.2 \mathrm{~g} / \mathrm{mL}$ followed by incubation for $30 \mathrm{~min}$ at $37^{\circ} \mathrm{C}$. The TTC reveals the presence of live bacteria by the appearance of a red color (Eloff 1998).

\section{Antioxidant activity: DPPH scavenging assay}

The hydrogen atoms or electrons donation ability of AEO was measured from the bleaching of a purple-colored methanol solution of DPPH (1,1-diphenyl-2-picryl hydrazyl) radical. In this study, $0.5 \mathrm{~mL}$ of each concentration of A-EO was homogenized with $0.5 \mathrm{~mL}$ of DPPH methanolic solution $(0.04 \mathrm{~g} / \mathrm{L})$. Then, this solution was incubated in darkness at a temperature of $25^{\circ} \mathrm{C}$ for 30 minutes. Afterward, the absorbance (A) of the obtained mixtures was measured at $517 \mathrm{~nm}$, and the percentage inhibition was calculated as follows (El-sharkawy et al. 2018):

$$
\% \text { Inhibition }=[(\text { A blank }-\mathrm{A} \text { sample }) / \mathrm{A} \text { blank }] \times 100
$$

Ascorbic acid was used as a positive control for this test and the concentration providing 50\% inhibition (IC50) was calculated from the graph of inhibition percentage plotted against the concentrations of A-EO.

\section{Antioxidant activity: Ferric reducing antioxidant power}

Ferric to ferrous ion reduction was used to determine the reductive capacity of A-EO (Ed-Dra et al. 2018a). Briefly, $1 \mathrm{~mL}$ of each concentration of A-EO was mixed with $2.5 \mathrm{~mL}$ of potassium hexacyanoferrate $\mathrm{K} 3 \mathrm{Fe}(\mathrm{CN})$ (Ed-Dra et al. 2018a) solution and $2.5 \mathrm{~mL}$ of phosphate buffer $(0.2 \mathrm{~mol} / \mathrm{L}, \mathrm{pH} 7.0)$ and incubated at $50^{\circ} \mathrm{C}$ for 30 min. Afterward, $2.5 \mathrm{~mL}$ of trichloroacetic acid (10\%) was added to the mixture. Then, $2.5 \mathrm{~mL}$ of this solution was homogenized with distilled water $(2.5 \mathrm{~mL})$ and $\mathrm{FeCl} 3(0.5$ $\mathrm{mL}, 0.1 \%)$. The absorbance was measured at $700 \mathrm{~nm}$ and the concentration of the samples at which the absorbance of 0.5 (EC50) was determined from the graph. Ascorbic acid was used as a positive control for comparison.

\section{Antioxidant activity: $\beta$-carotene bleaching assay}

The ability of A-EO to prevent bleaching of $\beta$-carotene was performed as described by Ait Sidi Brahim and his group (Ait Sidi Brahim et al. 2015). Briefly, a solution of the $\beta$-carotene-linoleic acid mixture was prepared by adding $0.5 \mathrm{~g}$ of $\beta$-carotene, $1 \mathrm{~mL}$ of chloroform, $25 \mu \mathrm{L}$ of linoleic acid, and $200 \mu \mathrm{L}$ of Tween 40 . The chloroform was then evaporated under vacuum at $40^{\circ} \mathrm{C}$ and $100 \mathrm{~mL}$ of distilled water was subsequently added to the residue and mixed smoothly forming a clear yellowish emulsion. In test tubes, $350 \mu \mathrm{L}$ of various concentrations of A-EO were added to $2.5 \mathrm{~mL}$ of the prepared emulsion and stirred vigorously. The test tubes were then incubated for $2 \mathrm{~h}$ at $50^{\circ} \mathrm{C}$ with negative control (blank) contained methanol instead of the EO. The absorbance values were measured at $470 \mathrm{~nm}$ and Butylhydroxytoluene (BHT) was used as a positive control. However, antioxidant activity (inhibitions percentages $\mathrm{I} \%$ ) of A-EO was calculated using the following formula:

\section{$\mathrm{I} \%=[(\mathrm{A} \beta-$ Carotene after 2 hours assay $/ \mathrm{A}$ initial $\beta-$ Carotene)] x 100}

Where $A$ ( $\beta$-carotene after $2 \mathrm{~h}$ assay) is the absorbance values of $\beta$-carotene after $2 \mathrm{~h}$ assay remaining in A-EO and A (initial $\beta$-carotene) is the absorbance value of $\beta$-carotene at the beginning of the experiment. The sample concentration providing 50\% inhibition (RC50) was calculated by plotting the inhibition percentage against the A-EO concentrations.

\section{Data analysis}

The measurements were carried out in triplicate. The data obtained were presented as means \pm standard error. Excel Microsoft software was used for data processing.

\section{RESULTS AND DISCUSSION}

\section{Essential oil extraction}

The A-EO extracted in this study presented yellow color with a strong penetrating pleasant herbaceous odor characteristic of the plant (Figure 2). The average yield of A-EO obtained from different distillation was $0.65 \pm 0.05 \mathrm{ml}$ 
from $100 \mathrm{~g}$ of dried aerial parts of the plant. This result is comparable to those found in the southeast of Algeria (0.62\%) (Dahmani-Hamzaoui and Baaliouamer 2010), and Southern Tunisia (0.68\%) (Mohsen and Ali 1999); higher than that found in Imouzzer Marmoucha region of Morocco during the period of March (0.2\%) (Btisam et al. 2016); and lower than those reported previously in Southwest $(0.86 \%$ and $0.97 \%)$ and Eastern (between 1.3 and $3.3 \%)$ regions of Morocco (Paolini et al. 2010; Amor et al. 2019), M'sila-Algeria (1.02\%) (Dob and Benabdelkader 2006), Jordan (1.3\%) (Hudaib and Aburjai 2006), and Tunisia (between $1.20 \%$ and 4.86\%) (Boukrich et al. 2010). Therefore, EOs yield may depend on several factors like climate conditions, geographical regions, harvested date, and the method used for extraction (Mohsen and Ali 1999; Boukrich et al. 2010; Dahmani-Hamzaoui and Baaliouamer 2010; Btisam et al. 2016).

\section{Chemical composition}

A total of 19 components were detected in A-EO, representing $88.29 \pm 0.25 \%$ of the total composition (Table $2)$. Among these, two constituents were unknown for a total of 17 identified compounds $(81.52 \pm 0.21 \%)$. The results of this study showed the dominance of oxygenated sesquiterpenes $(67.36 \pm 0.54 \%)$, which differ from those reported previously in other Moroccan studies, reporting the dominance of oxygenated monoterpenes (Paolini et al. 2010; El-sharkawy et al. 2018; Munda et al. 2019). However, the main components identified in this study were Davanone $(38.25 \pm 1.25 \%)$, Davana Ether Isomer 1 and $2(9.91 \pm 0.47 \%$ and $8.25 \pm 0.25 \%$, respectively), 1,2 Dehydro-3-hydroxyisodavanone $(6.33 \pm 0.67 \%)$ and Camphor $(6.31 \pm 0.16 \%)$ (Figure 3). It should be noted that Davanone was identified for the first time as the major component of A-EO harvested from Morocco. However, it was detected previously as the major component in A-EO from Djelfa region of Algeria (36.1\%) (DahmaniHamzaoui and Baaliouamer 2005), and southern Spain (51.2\%) (Salido et al. 2004). Moreover, this component dominates the EOs of other species of Artemisia such as $A$. absinthium collected from Ethiopia (21.3\%) (Asfaw and Demissew 2015), A. abyssinica collected from three habitats in Yemen $(49.4 \%, 43.5 \%$, and $32.3 \%$ ) (Chhetri et al. 2015), and A. indica Willd. collected from Uttarakhand Himalaya (North of India) (30.80\%) (Haider et al. 2014). On the other hand, Davana Ether Isomer, Camphor, and 1,2 Dehydro-3-hydroxyisodavanone were detected with a middle to lower concentration (traces) in A-EO from Morocco, Tunisia, Saudi Arabia, and Spain (Mohsen and Ali 2009; Ez zoubi et al. 2018; Amin et al. 2019; Amor et al. 2019).

The A-EO analyzed in this study could be classified into the chemotype "Davanone". However, chemotypes cis-thujone and $\beta$-thujone were reported in A-EO collected in the Azzemour region and Boulemane province in Morocco, respectively (Ez zoubi et al. 2018; Amor et al. 2019). In Tunisia, a study performed by Younsi et al. (2017) reported the distribution of chemotypes transsabinyl acetate, $\alpha$-thujone, and camphor among A-EO collected in different geographic and bioclimatic zones. Additionally, another Tunisian study identified four chemotypes (trans-sabinyl acetate, $\alpha$-thujone/trans-sabinyl acetate, camphor, and $\alpha$-thujone/camphor/ $\beta$-thujone) among the studied A-EO (Younsi et al. 2018), while A-EO chemotype "yomogi alcohol" was reported in a study carried out in Egypt (Amin et al. 2019). Therefore, the variability of volatile components in A-EO may depend on ecological conditions like the temperature of the warmest months, the annual rainfall, the humidity, and the evapotranspiration, as well as phenological stage, drying conditions, and methods used for extractions of EOs (Figueiredo et al. 2008; Boukrich et al. 2010; DahmaniHamzaoui and Baaliouamer 2010; Paolini et al. 2010; Btisam et al. 2016; Younsi et al. 2017; Aljaiyash et al. 2018). Additionally, it has been demonstrated that the chemical composition of A-EO could be correlated to the genetic diversity among the populations of A. herba-alba (Younsi et al. 2018).

\section{Antibacterial activity}

The disc diffusion method showed that A-EO has a heterogeneous antibacterial activity against the tested bacteria: $P$. aeruginosa $(9 \pm 0.1 \mathrm{~mm})$, E. faecalis $(13.4 \pm 0.3$ $\mathrm{mm}), K$. pneumonia $(13 \pm 0.3 \mathrm{~mm}), \quad$ S. Typhimurium $(13.5 \pm 0.2 \mathrm{~mm})$, E. coli $(14 \pm 0.2 \mathrm{~mm})$, E. coli ATCC 25922 $(16.5 \pm 0.3 \mathrm{~mm})$, and $S$. aureus $(17.2 \pm 0.5 \mathrm{~mm})$. The analysis of these results showed that A-EO presents a weak activity against $P$. aeruginosa, while against the other bacteria the activity ranges from intermediate to high (Figure 4). The broth dilution method showed that the MIC ranged between $0.156 \mathrm{mg} / \mathrm{mL}$ for $S$. aureus and $5 \mathrm{mg} / \mathrm{mL}$ for $P$. aeruginosa. Moreover, the ratio of MBC/MIC showed that A-EO presents a bactericidal activity with $\mathrm{MBC} / \mathrm{MIC} \leq 2$ (Table 3).

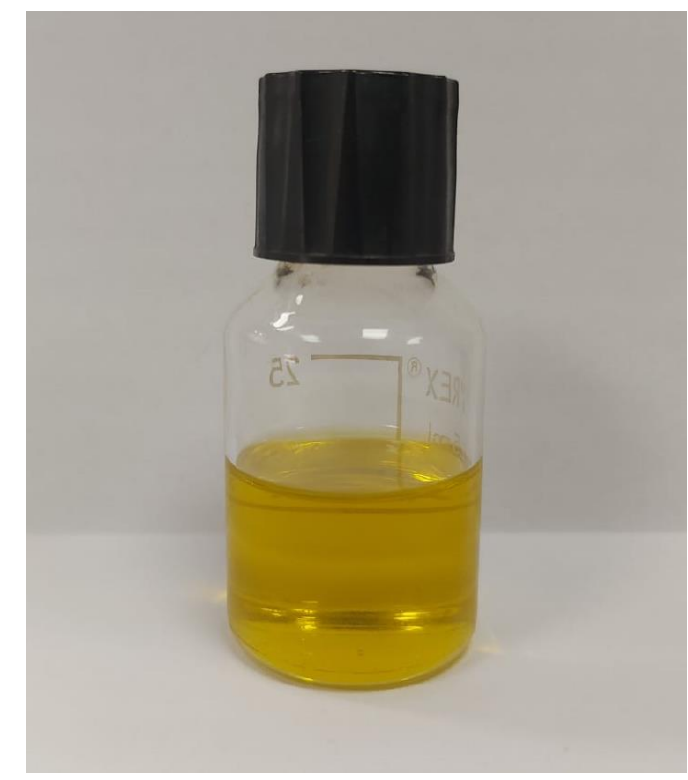

Figure 2. Study essential oil of Artemisia herba-alba 
Table 2. Chemical composition of the essential oil obtained from Artemisia herba-alba collected from semi-arid region of Talsint in the East of Morocco - approximately altitude of 1350 meter

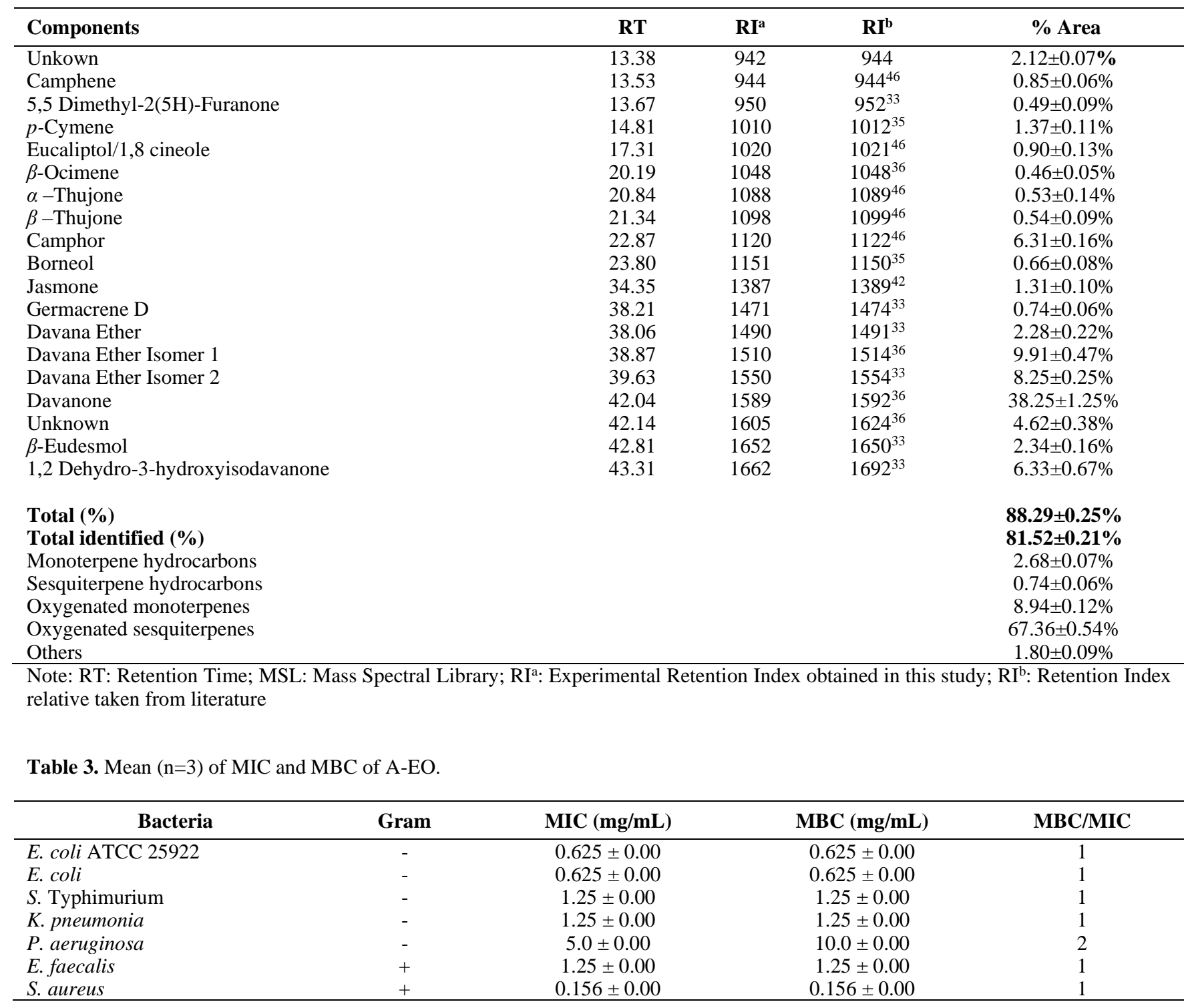

The results of this study showed an interesting antibacterial activity compared to those reported in other areas (Btisam et al. 2016; Amin et al. 2019). A study conducted by Amor and his group in the Azzemour region (Southwest Morocco) showed that A-EO was inactive against $E$. coli, E. faecalis, and $S$. aureus at a concentration of $10 \mu \mathrm{L}$ (Amor et al. 2019). Additionally, A-EO collected in Southern Tunisia was inactive on $P$. aeruginosa (Akrout et al. 2010). However, A-EO collected in the province of Boulemane (Middle Atlas, Morocco) showed inhibition zones between $12.2 \pm 0.6 \mathrm{~mm}$ and $25.2 \pm 2.6 \mathrm{~mm}$, and MIC between 2.5 and $20 \mu \mathrm{L} / \mathrm{mL}$ (Ez zoubi et al. 2018).

Generally, EOs of aromatic and medical plants were more effective against Gram-positive than Gram-negative bacteria. This phenomenon depends on EOs nature as well as the bacterial well composition (Burt 2004; Ed-Dra et al. 2020). The antibacterial activity of EOs may depend on oxygenated monoterpenes, diterpenes, and sesquiterpenes fractions. Some studies showed that these compounds interfere with the integrity and function of the cell membrane, changing the membrane potential, causing loss of cytoplasmic material, as well as on mitochondria leading to deficits of energy and respiratory metabolism (Burt 2004; Bakkali 2008) (Figure 5). However, the antibacterial mechanism of EOs is also influenced by the minor components that may act synergistic or in antagonistic with the major components. A study carried out by Viljoen and his group showed that camphor alone exhibited no antibacterial activity whereas it acts synergistically with other components possessing antimicrobial activity (Viljoen et al. 2003). Therefore, A-EO can be used in the pharmaceutical sector as precursors to synthesize new antibiotics against MDR bacteria (Abreu et al. 2012), or in food industries to extend the shelf life of food and improving their safety (Hyldgaard et al. 2012; Giarratana et al. 2016; Ed-Dra et al. 2018b). 

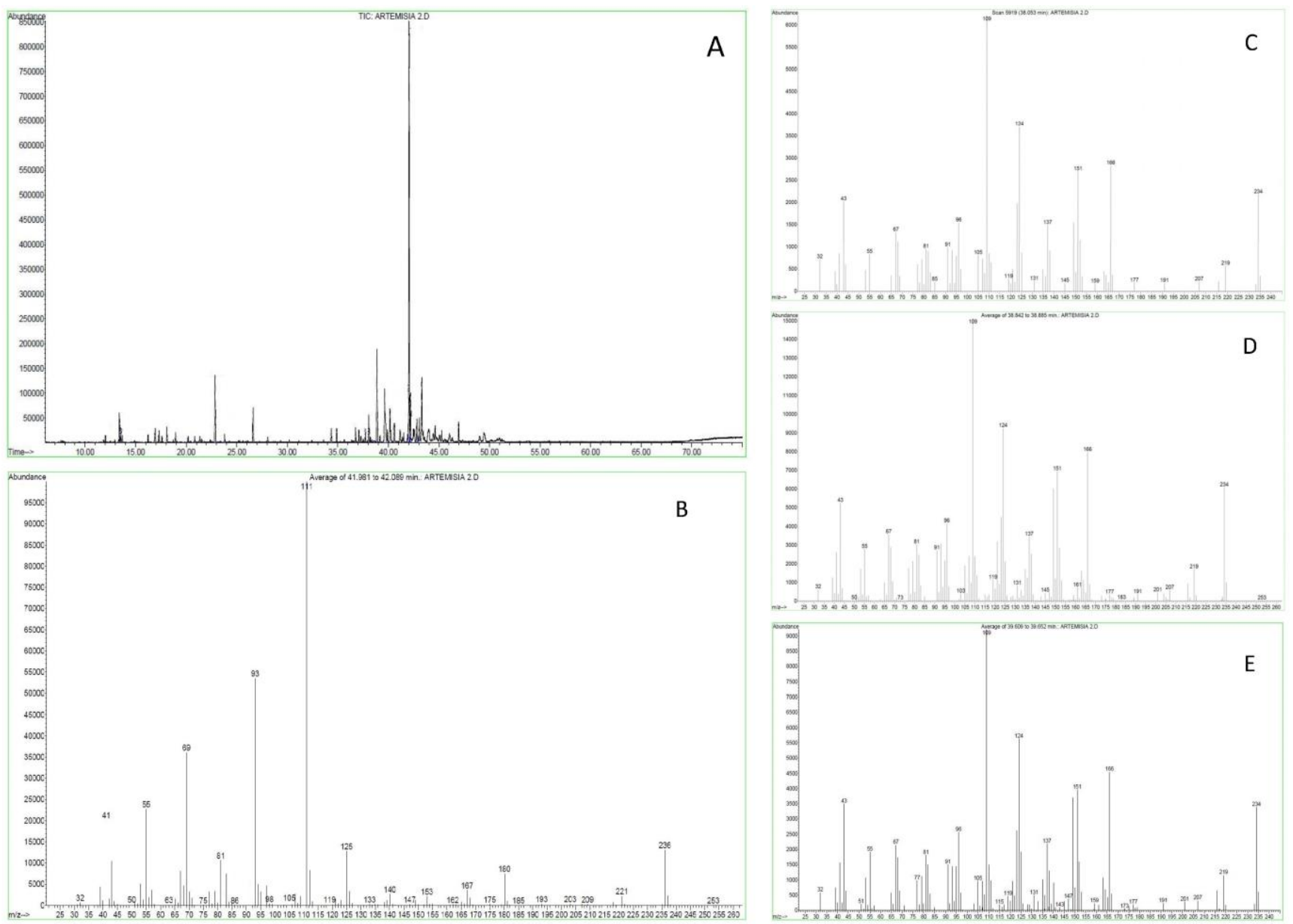

Figure 3. A: Mass spectra of A-EO; B: Mass spectra of Davanone; B: Mass spectra of Davana Ether; C: Mass spectra of Davana Ether Isomer 1; D: Mass spectra of Davana Ether Isomer 2.

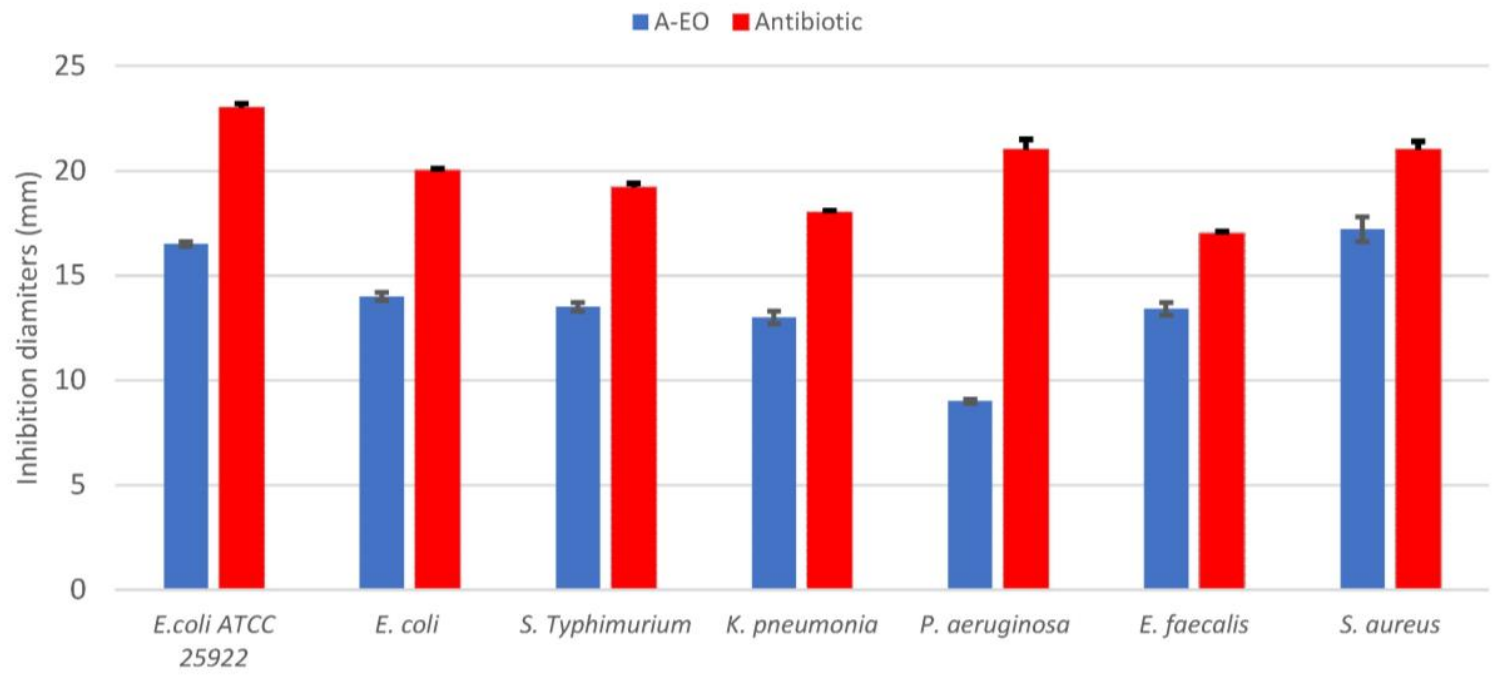

Figure 4. Inhibition diameters (mm) of the Artemisia herba-alba essential oil against the selected bacteria. Disc diameter $6.0 \mathrm{~mm}$. 


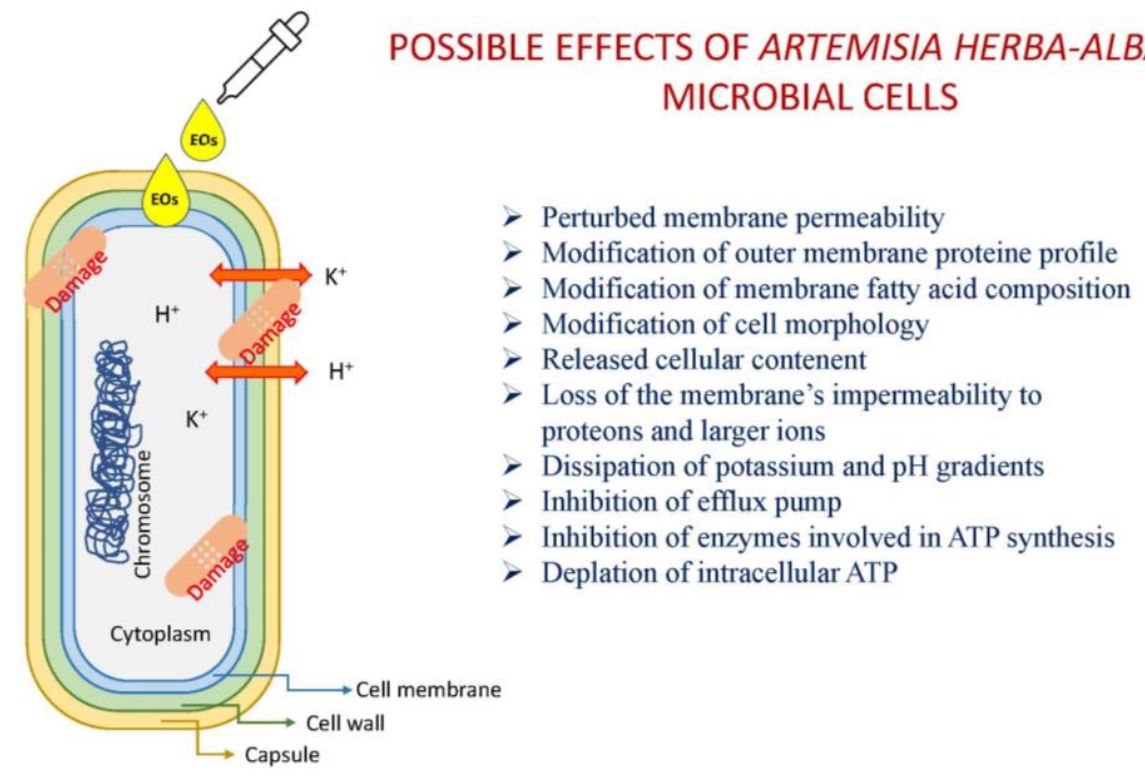

Figure 5. Mechanism of action of the Artemisia herba-alba essential oil against bacteria.

\section{Antioxidant activity}

The antioxidant activity was performed using DPPH scavenging activity, $\beta$-carotene bleaching assay, and reduction power of $\mathrm{Fe}$ (III) to $\mathrm{Fe}$ (II). The results of our study showed that A-EO has an interesting antioxidant activity with an IC50 of $1.13 \pm 0.02 \mathrm{mg} / \mathrm{mL}$, EC50 of $2.12 \pm 0.05 \mathrm{mg} / \mathrm{mL}$, and RC50 of $0.87 \pm 0.02 \mathrm{mg} / \mathrm{mL}$. The IC50 and EC50 of ascorbic acid were $0.032 \pm 0.003 \mathrm{mg} / \mathrm{mL}$ and $0.092 \pm 0.002 \mathrm{mg} / \mathrm{mL}$ respectively, while RC50 of BHT was $0.063 \pm 0.004 \mathrm{mg} / \mathrm{mL}$ (Table 4). These results were different from those reported previously in other regions of Morocco (Aljaiyash et al. 2018; Ez zoubi et al. 2018). However, they were comparable to those performed in semi-arid regions of Tunisia (Akrout et al. 2010; Kadri et al. 2011).

Generally, the high antioxidant activity of A-EO can be explained by its richness in natural components possessing conjugated systems that can trap electrons and free radicals (Mohamed et al. 2010). Moreover, it is well established that phenolic and chemical components with conjugated systems of double bonds usually show substantial antioxidant properties (Miguel 2010). Therefore, the richness of A-EO in Davanone, Davana Ether Isomer and 1,2 Dehydro-3-hydroxyisodavanone which possess a conjugated system, improves its antioxidant activity. Camphor and Spathulenol can participate alone or in combination with other components to improve the antioxidant power of EOs. A study carried out in Turkey on parental and drug-resistant cells showed that Camphor had an interesting cytoprotective (antioxidant) effect against $\mathrm{H}_{2} \mathrm{O}_{2}$ induced toxicity (Özkan and Erdoğan 2013). A study performed in Brazil by do Nascimento et al. (2018) demonstrated that Spathulenol has high antioxidant, antiinflammatory, and antiproliferative activities. However, the antioxidant properties of EOs do not always depend on the antioxidant activity of their main components, but they can be related to their other components taking into consideration also the concept of synergism, antagonism, and additivity between all the components (Dawidowicz and Olszowy 2014).

In this study, antioxidant activity was performed on the basis of three different assays in order to evaluate the capacity of A-EO to act against different mechanisms of oxidation. In fact, the DPPH assay allows the evaluation of the capacity of A-EO to capture and quench the free radicals (Gangwar et al. 2014). The reduction power of Fe (III) to Fe (II) assay allows the evaluation of the electrondonating capacity of A-EO which acts as an antioxidant agent to reduce Fe (III) to Fe (II) (Gülçin et al. 2015). Finally, the discoloration of a yellowish $\beta$-carotene solution related to the breaking of $\pi$-bond by addition of lipid or lipid peroxyl radical to a $\mathrm{C}=\mathrm{C}$ double bond of $\beta$-carotene is the principle on which the $\beta$-carotene bleaching assay is based (Ueno et al. 2014). Therefore, the results of this study showed that the three antioxidant assays demonstrate a great antioxidant activity of A-EO. These findings allow the use of A-EO in various fields, either in food preservation as an antioxidant agent to prevent the rancidity of food products that are sensitive to the reactions of oxidation or medical field to prevent and to treat the free radical-related disorders, which are the main cause of different chronic diseases.

Table 4. The antioxidant activity of A-EO

\begin{tabular}{cccc}
\hline & A-EO & Ascorbic acid & BHT \\
\hline $\mathrm{IC}_{50}(\mathrm{mg} / \mathrm{mL})$ & $1.13 \pm 0.02$ & $0.032 \pm 0.003$ & $\mathrm{nt}$ \\
$\mathrm{EC} 50(\mathrm{mg} / \mathrm{mL})$ & $2.12 \pm 0.05$ & $0.092 \pm 0.002$ & $\mathrm{nt}$ \\
$\mathrm{RC}_{50}(\mathrm{mg} / \mathrm{mL})$ & $0.87 \pm 0.02$ & $\mathrm{nt}$ & $0.063 \pm 0.004$ \\
\hline
\end{tabular}

Note: nt: not tested 
In conclusion, nowadays, MDR bacteria are major global concerns that require wide attention. In addition to providing correct information for a thrifty and targeted use of antibiotics both in human medicine and in animal breeding, the scientific community is called to monitoring the issue evaluation and find out new possible and valid alternatives. The results of the present study show how the A-EO could be an interesting option thanks to the observed antimicrobial and antioxidant activities. These properties are related to the biological effects of its constituents, the most abundant of which was represented by Davanone, reported for the first time as the major compound of A-EO harvested from Morocco. These natural properties could be used both in the medical field and food industry for treating bacterial infections and managing the risk of foodborne pathogens, respectively. Moreover, the cultivation of $A$. herba-alba for the production of EOs could be a new and important source of income for developing countries and the poorest populations in line with the requirements of the 2030 Agenda (UN General Assembly 2021). However, the present study was set up based on an in-vitro experiment which might overestimate the actual effectiveness of A-EO in a complex environment. Furthermore, the addition of EO in foods is conditioned by the influence on the sensory characteristics that could be excessively modified and not appreciated by the consumers. Therefore, further studies are needed to improve the knowledge of biological properties and to understand the real applicability of the AEO.

\section{ACKNOWLEDGEMENTS}

The authors thank Prof. Mohamed Ibn Tattou from Scientific Institute, Rabat (Morocco) for the identification of the plant, and Dr. Najia Moukrad from the Regional Hospital of Meknes (Mohammed V Hospital) for the bacterial strains.

\section{REFERENCES}

Abreu AC, McBain AJ, Simões M. 2012. Plants as sources of new antimicrobials and resistance-modifying agents. Nat Prod Rep 29: 1007-1021. DOI: 10.1039/c2np20035j

Ait Sidi Brahim M, Fadli M, Hassani L, Boulay B, Markouk M, Bekkouche K, Abbad A, Ait Ali M, Larhsini M. 2015. Chenopodium ambrosioides var. ambrosioides used in Moroccan traditional medicine can enhance the antimicrobial activity of conventional antibiotics. Ind Crops Prod 71: 37-43. DOI: 10.1016/j.indcrop.2015.03.067

Akrout A, Jani HEl, Amouri S, Neffati M. 2010. Screening of antiradical and antibacterial activities of essential oils of Artemisia campestris L., Artemisia herba alba Asso, \& Thymus capitatus Hoff. et Link. Growing wild in the Southern of Tunisia. Recent Res Sci Technol 2: 29-39.

Aljaiyash A, Kasrati A, Alaoui Jamali C, Chaouch A. 2018. Effect of cultivation on chemical composition and bioactivities of essential oils from Artemisia herba-alba Asso grown in Morocco. Biochem Syst Ecol 81: 74-79. DOI: 10.1016/j.bse.2018.10.001.

Amin SM, Hassan HM, El Gendy AENG, El-Beih AA, Mohamed TA, Elshamy AI, Bader A, Shams KA, Mohammed R, Hegazy MEF. 2019. Comparative chemical study and antimicrobial activity of essential oils of three Artemisia species from Egypt and Saudi Arabia. Flavour Fragr J 34: 450-459. DOI: 10.1002/ffj.3525.
Amor G, Caputo L, La Storia A, De Feo V, Mauriello G, Fechtali T. 2019. Chemical composition and antimicrobial activity of Artemisia herbaalba and Origanum majorana essential oils from Morocco. Molecules 24: 4021. DOI: 10.3390/molecules24224021.

Amuka O, Okemo P, Machocho A, Mbugua P, Njagi EMN, Nyamache A. 2013. The role of phytomedicine in the challenges of emerging, reemerging diseases; and pathogens resistance to antibiotics. Int J Herb Med 1 (4): 92-101. DOI: 10.4314/bcse.v29i1.11.

Anand U, Jacobo-Herrera N, Altemimi A, Lakhssassi N. 2019. A comprehensive review on medicinal plants as antimicrobial therapeutics: Potential avenues of biocompatible drug discovery. Metabolites 9 (11): 258. DOI: 10.3390/metabo9110258.

Anand U, Nandy S, Mundhra A, Das N, Pandey DK, Dey A. 2020. A review on antimicrobial botanicals, phytochemicals and natural resistance modifying agents from Apocynaceae family: Possible therapeutic approaches against multidrug resistance in pathogenic microorganisms. Drug Resist Update 51: 100695-100695. DOI: 10.1016/j.drup.2020.100695.

Asfaw N, Demissew S. 2015. Essential oil composition of four Artemisia species from Ethiopia. Bull Chem Soc Ethiopia 29: 123-128. DOI: 10.4314/bcse.v29i1.11.

Bakkali F, Averbeck S, Averbeck D, Idaomar M. 2008. Biological effects of essential oils - A review. Food Chem Toxicol 46: 446-475. DOI: 10.1016/j.fct.2007.09.106

Bohnert HJ, Nelson DE, Jensen RG. 1995. Adaptations to environmental stresses. Plant Cell 7: 1099-1111. DOI: 10.1105/tpc.7.7.1099.

Boukrich F, Zouari S, Neffati M, Abdelly C, Liu K, Casanova J, Tomi F. 2010. Chemical variability of Artemisia herba-alba asso growing wild in semi-arid and arid land (Tunisia). J Essent Oil Res 22: 331335. DOI: 10.1016/j.arabjc.2012.04.042.

Bouymajane A, Filali FR, Oulghazi S, Ed-Dra A, Benhallam F, El Allaoui A, Anissi J, Sendide K, Ouhmidou B, Moumni M. 2018. Occurrence, molecular and antimicrobial resistance of Enterococcus spp. Isolated from raw cow's milk trade by street trading in Meknes city, Morocco. Germs 8: 77-84. DOI: 10.18683/germs.2018.1134.

Btisam O, Mohamed G, Badr S, Lahsen EG, Mariam F, Mounyr B, Elhassan EH, Benaissa K, Salah Eddine BY. 2016. Effect of harvest date on yield, chemical composition and antimicrobial activity of Artemisia herba-alba essential oil. Int J Sci Eng Res 7: 600-606.

Burt S. 2004. Essential oils: their antibacterial properties and potential applications in foods-a review. Intl J Food Microbiol 94: 223-253. DOI: 10.1016/j.ijfoodmicro.2004.03.022.

Caceres A, Cano O, Samayoa B, Aguilar L. 1990. Plants used in Guatemala for the treatment of gastrointestinal disorders. 1. Screening of 84 plants against Enterobacteria. J Ethnopharmacol 30: 55-73. DOI: 10.1016/0378-8741(90)90017-N.

Chebaibi A, Marouf Z, Rhazi-Filali F, Fahim M, Ed-Dra A. 2016. Evaluation of antimicrobial activity of essential oils from seven Moroccan medicinal plants. Phytotherapie 14: 355-362. DOI: 10.1007/s10298-015-0996-1.

Chhetri BK, Al-Sokari SS, Setzer WN, Ali NAA. 2015. Essential oil composition of Artemisia abyssinica from three habitats in Yemen. Am J Essent Oils Nat Prod 2: 28-30. DOI: 10.3390/medicines2020067.

CLSI. 2014. Performance Standards for Antimicrobial Susceptibility Testing; Twenty-Fourth Informational Supplement. Clinical Laboratory Standards Institute, USA.

Dahmani-Hamzaoui N, Baaliouamer A. 2005. Chemical composition of the essential oil of Algerian Artemisia herba alba from Djelfa. Riv Italia EPPOS 40: 7-13.

Dahmani-Hamzaoui N, Baaliouamer A. 2010. Chemical composition of algerian Artemisia herba-alba essential oils isolated by microwave and hydrodistillation. J Essent Oil Res 22: 514-517. DOI: 10.1080/10412905.2010.9700386

Dawidowicz AL, Olszowy M. 2014. Does antioxidant properties of the main component of essential oil reflect its antioxidant properties? The comparison of antioxidant properties of essential oils and their main components. Nat Prod Res 28: 1952-1963. DOI: 10.1080/14786419.2014.918121.

do Nascimento KF, Moreira FMF, Alencar Santos J, Kassuya CAL, Croda JHR, Cardoso CAL, Vieira MDC, Góis Ruiz ALT, Foglio MA, de Carvalho JE, Formagio ASN. 2018. Antioxidant, anti-inflammatory, antiproliferative and antimycobacterial activities of the essential oil of Psidium guineense Sw. and spathulenol. J Ethnopharmacol 210: 351358. DOI: 10.1016/j.jep.2017.08.030. 
Dob T, Benabdelkader T. 2006. Chemical composition of the essential oil of Artemisia herba-alba Asso grown in Algeria. J Essent Oil Res 18: 685-690. DOI: 10.1080/10412905.2006.9699206.

Ed-Dra A, Filai FR, Bou-Idra M, Zekkori B, Bouymajane A, Moukrad N, Benhallam F, Bentayeb A. 2018a. Application of Mentha suaveolens essential oil as an antimicrobial agent in fresh turkey sausages. J. Appl Biol Biotechnol 6: 7-12. DOI: 10.7324/JABB.2018.60102.

Ed-Dra A, Filali FR, Bouymajane A, Benhallam F, El Allaoui A, Chaiba A, Giarratana F. 2018b. Antibiotic susceptibility profile of Staphylococcus aureus isolated from sausages in Meknes, Morocco. Vet World 11: 1459-1465. DOI: 10.14202/vetworld.2018.1459-1465.

Ed-Dra A, Filali FR, Khayi S, Oulghazi S, Bouchrif B, El Allaoui A, Ouhmidou B, Moumni M. 2019. Antimicrobial resistance, virulence genes, and genetic diversity of Salmonella enterica isolated from sausages. Eur J Microbiol Immunol 9: 56-61. DOI: 10.1556/1886.2018.00035

Ed-Dra A, Filali FR, Lo Presti V, Zekkori B, Nalbone L, Bouymajane A Trabelsi N, Lamberta F, Bentayeb A, Giuffrida A, Giarratana F. 2020 Chemical composition, antioxidant capacity and antibacterial action of five Moroccan essential oils against Listeria monocytogenes and different serotypes of Salmonella enterica. Microb Pathog 149: 104510. DOI: 10.1016/j.micpath.2020.104510.

Ed-Dra A, Nalbone L, Filali FR, Trabelsi N, El Majdoub YO, Bouchrif B, Giarratana F, Giuffrida A. 2021. Comprehensive evaluation on the use of Thymus vulgaris essential oil as natural additive agains different serotypes of Salmonella enterica. Sustainability 13 (8): 4594. DOI: 10.3390/su13084594.

EFSA, ECDC. 2018. The European Union summary report on antimicrobial resistance in zoonotic and indicator bacteria from humans, animals and food in 2016. EFSA J 16: 5182. DOI: 10.2903/j.efsa.2018.5182.

Eloff JN. 1998. A sensitive and quick microplate method to determine the minimal inhibitory concentration of plant extracts for bacteria. Planta Med 64: 711-713.

El-Shakawy ER, Ed-Dra A, Abdallah EM. 2017. Phytochemical, antimicrobial and antioxidant properties of Launaea nudicaulis and Farsetia hamiltonii. J Biol Control 31: 102-109. DOI: $10.18311 / \mathrm{jbc} / 2017 / 15910$.

El-Sharkawy ER, Ed-Dra A, Alghanem S, Abdallah EM. 2018. Comparative studies of chemical composition, antimicrobial and antioxidant activity of essential oil of some species from genus Artemisia. J Nat Remedies 18: 10-20. DOI: 10.18311/jnr/2018/20052.

Ez zoubi Y, Lairini S, Farah A, Taghzouti K, El Ouali Lalami A. 2018. Antioxidant and antibacterial activities of Artemisia herba-alba essential oil from middle Atlas, Morocco. Phytotherapie 16: S48-S54. DOI: 10.3166/phyto-2018-0057.

Fennane M, Ibn Tattou M, Mathez J, Ouyahya A, EL Oualidi J. 1999 Flore pratique du Maroc: manuel de détermination des plantes vasculaires. Pteridophyta, Gymnospermae, Angiospermae (Lauraceae-Neuradaceae). Institut scientifique, France. [French]

Figueiredo AC, Barroso JG, Pedro LG, Scheffer JJC. 2008. Factor affecting secondary metabolite production in plants: Volatile components and essential oils. Flavour Fragr J 23: 213-226. DOI: 10.1002/ffj. 1875

Gacem MA, El Hadj-Khelil AO, Boudjemaa B, Gacem H. 2020 Phytochemistry, Toxicity and Pharmacology of Pistacia lentiscus, Artemisia herba-alba and Citrullus colocynthis. In: Lichtfouse E (eds) Sustainable Agriculture Reviews 39. Sustainable Agriculture Reviews, vol 39. Springer, Cham. DOI: 10.1007/978-3-030-38881 2_3.

Galieni A, Di Mattia C, De Gregorio M, Speca S, Mastrocola D, Pisante M, Stagnari F. 2015. Effects of nutrient deficiency and abiotic environmental stresses on yield, phenolic compounds and antiradical activity in lettuce (Lactuca sativa L.). Sci Hortic 187: 93-101. DOI 10.1016/j.scienta.2015.02.036

Gangwar M, Gautam MK, Sharma AK, Tripathi YB, Goel RK, Nath G. 2014. Antioxidant capacity and radical scavenging effect of polyphenol rich Mallotus philippenensis fruit extract on human erythrocytes: An in vitro study. Sci World J 279451. DOI: $10.1155 / 2014 / 279451$

Giarratana F, Muscolino D, Beninati C, Giuffrida A, Panebianco A. 2014 Activity of Thymus vulgaris essential oil against Anisakis larvae. Exp Parasitol 142: 7-10. DOI: 10.1016/j.exppara.2014.03.028.

Giarratana F, Muscolino D, Beninati C, Ziino G, Giuffrida A, Panebianco A. 2013. Effects of thyme and rosemary essential oils on the microbiology and shelf life of Italian Mortadella. Fleischwirtschaft 93 (4): 183-187

Giarratana F, Muscolino D, Ragonese C, Beninati C, Sciarrone D, Ziino G, Mondello L, Giuffrida A, Panebianco A. 2016. Antimicrobial activity of combined thyme and rosemary essential oils against Listeria monocytogens in Italian mortadella packaged in modified atmosphere: Thyme \& Rosemary EOs vs L. monocytogenes. J Essent Oil Res 28: 467-474. DOI: 10.1080/10412905.2016.1165744.

Giarratana F, Muscolino D, Ziino G, Lo Presti V, Rao R, Chiofalo V, Giuffrida A, Panebianco A. 2017. Activity of catmint (Nepeta cataria) essential oil against anisakis larvae. Trop Biomed 34: 22-31.

Gülçin L. 2015. Fe3+-Fe2+ transformation method: An important antioxidant assay. Methods Mol Biol 1208: 233-246. DOI: 10.1007/978-1-4939-1441-8_17

Haider SZ, Mohan M, Andola HC. 2010. Constituents of Artemisia indica Willd. from Uttarakhand Himalaya: A source of davanone. Pharmacognosy Res 6: 257-259. DOI: 10.4103/0974-8490.132607.

Hendawy SF, El Gendy AG, Omer EA, Pistelli L, Pistelli L. 2018. Growth, yield and chemical composition of essential oil of Mentha piperita var. multimentha grown under different agro-ecological locations in Egypt. J Essent Oil-Bearing Plants 21: 23-39. DOI: 10.1080/0972060X.2017.1423247.

Hirota R, Roger NN, Nakamura H, Song HS, Sawamura M, Suganuma N. 2010. Anti-inflammatory effects of limonene from yuzu (Citrus junos tanaka) essential oil on eosinophils. J Food Sci 75: H87-H92. DOI: 10.1111/j.1750-3841.2010.01541.x

Hudaib MM, Aburjai TA. 2006. Composition of the essential oil from Artemisia herba-alba grown in Jordan. J Essent Oil Res 18: 301-304. DOI: 10.1080/10412905.2006.9699096.

Hyldgaard M, Mygind T, Meyer RL. 2012. Essential oils in food preservation: Mode of action, synergies, and interactions with food matrix components. Front Microbiol 3: 12. DOI: 10.3389/fmicb.2012.00012.

Jamila F, Mostafa E. 2014. Ethnobotanical survey of medicinal plants used by people in Oriental Morocco to manage various ailments. J Ethnopharmacol 154: 76-87. DOI: 10.1016/j.jep.2014.03.016.

Kadri A, Ben Chobba I, Zarai Z, BéKir A, Gharsallah N, Damak M, Gdoura R. 2011. Chemical constituents and antioxidant activity of the essential oil from aerial parts of Artemisia herba-alba grown in Tunisian semi-arid region. Afr J Biotechnol 10: 2923-2929. DOI: 10.5897/AJB10.2491

Kordali S, Kotan R, Mavi A, Cakir A, Ala A, Yildirim A. 2005. Determination of the chemical composition and antioxidant activity of the essential oil of Artemisia dracunculus and of the antifungal and antibacterial activities of Turkish Artemisia absinthium, Artemisia dracunculus, Artemisia santonicum, and Artemisia spicig. J Agric Food Chem 53: 9452-9458. DOI: 10.1021/jf0516538.

Langeveld WT, Veldhuizen EJ, Burt SA. 2014. Synergy between essential oil components and antibiotics: a review. Crit Rev Microbiol 40 (1): 76-94. DOI: 10.3109/1040841X.2013.763219.

Lu XG, Zhan LB, Feng BA, Qu MY, Yu LH, Xie JH. 2004. Inhibition of growth and metastasis of human gastric cancer implanted in nude mice by D-limonene. World J Gastroenterol 10: 2140-2144. DOI: 10.3748/wjg.v10.i14.2140.

Maroui I, Barguigua A, Aboulkacem A, Ouarrak K, Sbiti M, Louzi H, Timinouni M, Belhaj A. 2016. First report of VIM-2 metallo- $\beta$ lactamases producing Pseudomonas aeruginosa isolates in Morocco. J Infect Chemother 22: 127-132. DOI: 10.1016/j.jiac.2015.11.008.

Miguel MG. 2010. Antioxidant and anti-inflammatory activities of essential oils: A short review. Molecules 15: 9252-9287. DOI: 10.3390/molecules15129252.

Mohamed AEHH, El-Sayed MA, Hegazy ME, Helaly SE, Esmail AM, Mohamed NS. 2010. Chemical constituents and biological activities of Artemisia herba-alba. Rec Nat Prod 4: 1-25. DOI: 10.3390/molecules24224021.

Mohammed MJ, Anand U, Altemimi AB, Tripathi V, Guo Y, PratapSingh A. 2021. Phenolic composition, antioxidant capacity and antibacterial activity of white wormwood (Artemisia herba-alba). Plants 10 (1): 164. DOI: 10.3390/plants10010164.

Mohsen H, Ali F. 2009. Essential oil composition of Artemisia herba-alba from Southern Tunisia. Molecules 14: 1585-1594. DOI: 10.3390/molecules14041585.

Munda S, Pandey SK, Dutta S, Baruah J, Lal M. 2019. Antioxidant activity, antibacterial activity and chemical composition of essential oil of Artemisia vulgaris L. leaves from Northeast India. J Essent Oil- 
$\begin{array}{llll}\text { Bearing Plants } 22 & \text { (2): } 368-379 . & \text { DOI: }\end{array}$ 10.1080/0972060X.2019.1602083.

Ouaritini ZB, Chraibi M, Benbrahim KF, Ez-zriouli R, Boukhira S, Darkaoui N, Derwich H. 2016. Phytochemical and antibacterial activity of the essential oil of Artemisia herba-alba from Morocco. IOSR J Pharm Biol Sci 11: 40-45.

Özkan A, Erdoğan A. 2013. Membrane and DNA damaging/protective effects of eugenol, eucalyptol, terpinen-4-ol, and camphor at various concentrations on parental and drug-resistant H1299 cells. Turkish J Biol 37: 405-413. DOI: 10.3906/biy-1208-4.

Paolini J, El Ouariachi EM, Bouyanzer A, Hammouti B, Desjobert JM, Costa J, Muselli A. 2010. Chemical variability of Artemisia herba alba Asso essential oils from East Morocco. Chem Pap 64: 550-556. DOI: 10.7324/JAPS.2016.60705.

Pluchtová M, Gervasi T, Benameur Q, Pellizzeri V, Grul'ová D, Campone L, Sedlák V, Cicero N. 2018. Antimicrobial activity of two mentha species essential oil and its dependence on different origins and chemical diversity. Nat Prod Commun 13: 1051-1054. DOI: 10.1177/1934578X1801300832.

Salido S, Valenzuela LR, Altarejos J, Nogueras M, Sánchez A, Cano E. 2004. Composition and infraspecific variability of Artemisia herbaalba from southern Spain. Biochem Syst Ecol 32: 265-277. DOI: 10.1016/j.bse.2003.09.002.

Telci I, Bayram E, Yilmaz G, Avcı B. 2006. Variability in essential oil composition of Turkish basils (Ocimum basilicum L.). Biochem Syst Ecol 34 (6): 489-497. DOI: 10.1016/j.bse.2006.01.009.

Trabelsi N, Nalbone L, Di Rosa AR, Ed-Dra A, Nait-Mohamed S, Mhamdi R, Giuffrida A, Giarratana F. 2021. Marinated anchovies (Engraulis encrasicolus) prepared with flavored olive oils (Chétoui cv.): Anisakicidal effect, microbiological, and sensory evaluation. Sustainability 13 (9): 5310. DOI: 10.3390/su13095310.

Trabelsi N, Nalbone L, Marotta SM, Taamali A, Abaza L, Giarratana F. 2019. Effectiveness of five flavored Tunisian olive oils on Anisakis larvae type 1: application of cinnamon and rosemary oil in industrial anchovy marinating process. J Sci Food Agric 99: 4808-4815. DOI: $10.1002 /$ jsfa. 9736.

Ueno H, Yamakura S, Arastoo RS, Oshima T, Kokubo K. 2014. Systematic evaluation and mechanistic investigation of antioxidant activity of fullerenols using $\beta$-Carotene bleaching assay. J Nanomater ID 802596. DOI: $10.1155 / 2014 / 802596$.

UN General Assembly. 2021. 2030 Agenda. UN General Assembly, Transforming our world: the 2030 Agenda for Sustainable Development, $21 \quad$ October 2015, A/RES/70/1. www.refworld.org/docid/57b6e3e44.html [accessed 28 June 2021]

Viljoen A, Van Vuuren S, Ernst E, Klepser M, Demirci B, Başer H, Van Wyk BE. 2003. Osmitopsis asteriscoides (Asteraceae)-the antimicrobial activity and essential oil composition of a Cape-Dutch remedy. J Ethnopharmacol 88: 137-143. DOI: 10.1016/s03788741(03)00191-0.

Viuda-Martos M, Ruiz-Navajas Y, Fernández-López J, Pérez-Álvarez J. 2008. Antifungal activity of lemon (Citrus lemon L.), mandarin (Citrus reticulata $\mathrm{L}$.), grapefruit (Citrus paradisi L.) and orange (Citrus sinensis L.) essential oils. Food Control 19: 1130-1138. DOI: 10.1016/j.foodcont.2007.12.003.

World Health Organization. 2017. Global priority list of antibioticresistant bacteria to guide research, discovery, and development of new antibiotics. World Heal. Organ. 2017. www.who.int/medicines/publications/global-priority-list-antibioticresistant-bacteria/en/.

Younsi F, Mehdi S, Aissi O, Rahali N, Jaouadi R, Boussaid M, Messaoud C. 2017. Essential oil variability in natural populations of Artemisia campestris (L.) and Artemisia herba-alba (Asso) and incidence on antiacetylcholinesterase and antioxidant activities. Chem Biodivers 14 (7): e1700017. DOI: 10.1002/cbdv.201700017.

Younsi F, Rahali N, Mehdi S, Boussaid M, Messaoud C. 2018. Relationship between chemotypic and genetic diversity of natural populations of Artemisia herba-alba Asso growing wild in Tunisia. Phytochemistry 148: 48-56. DOI: 10.1016/j.phytochem.2018.01.014. 